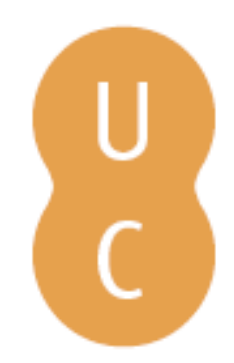

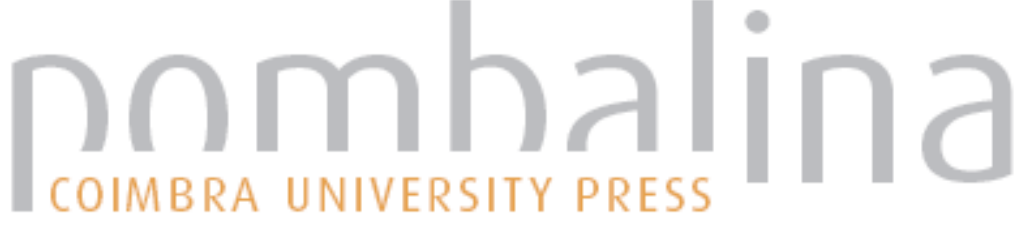

Management of firebrand potential through the candling of bark fuel

Autor(es): $\quad$ Duff, Thomas J.; Richards, Penny; Cawson, Jane G.

Publicado por: Imprensa da Universidade de Coimbra

URL

persistente: URI:http://hdl.handle.net/10316.2/44544

DOI: $\quad$ DOI:https://doi.org/10.14195/978-989-26-16-506_27

Accessed : $\quad$ 26-Apr-2023 11:01:36

A navegação consulta e descarregamento dos títulos inseridos nas Bibliotecas Digitais UC Digitalis, UC Pombalina e UC Impactum, pressupõem a aceitação plena e sem reservas dos Termos e Condições de Uso destas Bibliotecas Digitais, disponíveis em https://digitalis.uc.pt/pt-pt/termos.

Conforme exposto nos referidos Termos e Condições de Uso, o descarregamento de títulos de acesso restrito requer uma licença válida de autorização devendo o utilizador aceder ao(s) documento(s) a partir de um endereço de IP da instituição detentora da supramencionada licença.

Ao utilizador é apenas permitido o descarregamento para uso pessoal, pelo que o emprego do(s) título(s) descarregado(s) para outro fim, designadamente comercial, carece de autorização do respetivo autor ou editor da obra.

Na medida em que todas as obras da UC Digitalis se encontram protegidas pelo Código do Direito de Autor e Direitos Conexos e demais legislação aplicável, toda a cópia, parcial ou total, deste documento, nos casos em que é legalmente admitida, deverá conter ou fazer-se acompanhar por este aviso. 


\section{ADVANCES IN}

\section{FOREST FIRE RESEARCH}

\section{8}

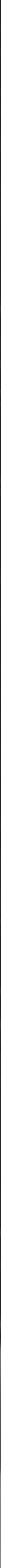




\title{
Management of firebrand potential through the candling of bark fuel
}

\author{
Thomas J. Duff*; Penny Richards; Jane G. Cawson \\ University of Melbourne, Burnley, Australia \\ \{tjduff@unimelb.edu.au*,p.richards@student.unimelb.edu.au, jane.cawson@unimelb.edu.au\}
}

\begin{abstract}
Aerially suspended fuels play an important role in forest fire behaviour. They can act as a ladder to flames, increasing the potential for crownfire, and can ignite and act as firebrands. When large accumulations of these fuels are present, wildfires may spread more rapidly, be more difficult to suppress and be more likely to impact assets such as houses. However, as these fuels are suspended above the ground, their moisture status is predominantly a function of atmospheric humidity. As a result, bark and suspended fuels may become flammable at times when the remainder of the fuel bed is too wet to burn due to high soil moisture levels. This means that these fuels can be reduced by burning when conditions are unfavourable for prescribed burning using the practice candling. Candling is the deliberate ignition of bark and other dead fine ladder fuels under conditions where surface fires are unlikely to spread. We compared the number of days available for prescribed burning and candling for a locality in South Eastern Australia and found that in the period 2012 - 2016, candling could be undertaken for an average 124 days per year, 48 days more than the window available for prescribed burning (76 days). As each accumulation of aerial fuel must be individually lit during candling, the practice is labour intensive and inefficient over large areas relative to prescribed burning, so it is best used for targeted risk reduction such as near control lines or assets. However, it can be used to reduce risk with low chance of escape in locations where prescribed burning is difficult such as the Wildland Urban Interface. The practice is applied operationally in South Eastern Australia, however to date there has been limited research into its effects on wildfire spread and intensity. Given its suitability for strategic use near highly vulnerable assets, we believe further investigation into its utility is warranted.
\end{abstract}

Keywords: burn window; embers; firebrand; fuel management; hazard; prescribed burn, torching; spotting

\section{Introduction}

In forests, aerially held dead fine fuels can play important roles in fire behaviour. During wildfires these fuels can ignite rapidly, act as ladder between the surface fuels and tree canopy and dislodge to become firebrands (Billing and Bywater 1982; Hines et al. 2010; Ellis 2011).

Aerially held dead fine fuels can increase the intensity of wildfires by allowing a greater amount of biomass to be encompassed in the flaming front. They do this by providing a ladder from burning surface / near surface fuels to the crowns of trees. This allows flames to bridge the gap between the overstorey and understorey, facilitating the occurrence of crownfires (Jenkins et al. 2012). During crown fires, fire spread rate is enhanced, suppression becomes ineffective and the likelihood of detrimental ecological impacts is increased (Stephens and Finney 2002; Alexander and Cruz 2011; Hoffman et al. 2016).

Firebrands - burning fragments of material - can enhance wildfire progression where they are carried by winds ahead of the fire area to start new spotfires (McArthur 1967). Under extreme conditions the spread of fire via the coalescence of spotfires can be the primary driver of wildfire spread (Cheney and Bary 1969; Cruz et al. 2012). Firebrands also allow fires to traverse fuel discontinuities, limiting the effectiveness of fire suppression (Koo et al. 2010). Additionally, they are the dominant ignition source for houses during wildfires (Blanchi and Leonard 2005). 
The bark of one genus of trees is recognised for its contribution to spotting in damaging wildfires worldwide, Eucalyptus. Eucalypts typically either have smooth bark that is shed annually or fibrous 'stringy' bark that is retained (Blanchi and Leonard 2005). The fibrous trunks of species such as $E$. obliqua are easily ignited, and the loosely held nature of its bark means that they produce copious amounts of small firebrands (Fig 1).

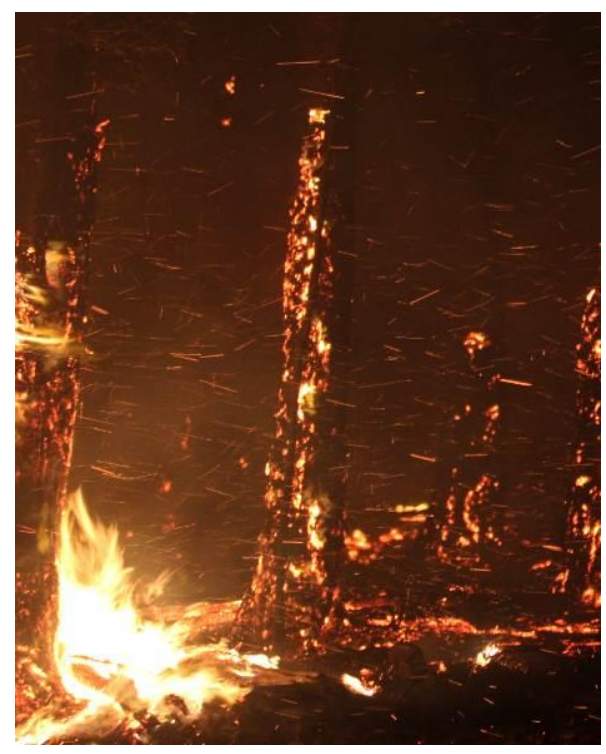

Figure 1 - Firebrands from Eucalyptus obliqua trees during an autumn prescribed burn adjacent to a control line

Dead aerial fuels have typically been managed in conjunction with other fuels. This has predominantly been through prescribed burning. Prescribed burning can be an effective way to modify dead aerial fuels in forests, reducing the total amount, altering properties and reducing bark ignitability by creating a layer of char on tree boles (Chatto et al. 2003; Penman et al. 2017). Effective prescribed burning can only be done within a particular range of weather conditions - the burn window - whereby a forested site is dry enough to be flammable, but not so dry that a burn is likely to escape control and become a wildfire (Slijepcevic et al. 2015). Burn windows typically occur at the fringes of the dry season, but can vary greatly interannually. The timing and lighting patterns of burns can be used to manage fire behaviour, allowing large areas to be burnt with few material inputs. Prescribed burning comes with a risk of escape (Tolhurst and Cheney 1999); escaped burns can have adverse impacts, particularly where there are concentrations of high value assets such as in the Wildland Urban Interface (WUI). As a result, prescribed burning requires high levels of planning, investment in specialised firefighting equipment and the need to have crews at hand when weather conditions are favourable. The unpredictability of weather may also mean that particular burns may not be completed when scheduled.

Given the importance of aerially suspended dead fine fuels to fire behaviour, it is important to be able to effectively reduce its hazard. In particular, in the WUI, aerially suspended fuels pose a high risk to assets, but are difficult to manage using prescribed burning due to the high potential losses in the event of fires escaping. Here we describe and evaluate an alternative method, Candling. Candling is a method of burning bark and other dead fine fuels on the tree bole and branches under conditions where fire spread will be limited by high levels of landscape moisture. We compare the conditions under which candling can be carried out relative to prescribed burning to evaluate its suitability for use in temperate climates such as South-Eastern Australia. 


\section{Methods}

\subsection{The practice of candling}

Candling is the practice of igniting bark or dead material held on individual tree boles in a manner that allows flames to climb the trunk and burn out the majority of dead aerial fine fuel (Billing and Bywater 1982). To effectively burn this material, it must be in a dry enough state to burn. As it is aerially suspended, its moisture status is predominantly a function of atmospheric humidity which can vary greatly over short periods. Surface fuels are in contact with the ground and consequently are strongly influenced by soil moisture which varies more gradually. As a result, aerial fine fuels can be flammable under conditions where the remainder of the fuel bed is too wet to burn. Ideal candling conditions are where the suspended fuels are flammable, but high surface fuel moistures mean that there is little or no potential for fire spread. Draft prescriptions for undertaking candling in South Eastern Australia are presented in Table 1. These have been developed collaboratively by the Victorian Department of Environment, Land, Water and Planning (DELWP), and the Country Fire Authority.

Table 1 - Draft prescriptions to undertake candling and prescribed burning of fibrous tree bark when in natural forest with a shrubby understorey in Victoria, Australia

\begin{tabular}{|c|c|c|}
\hline Parameter & Candling & Prescribed burning \\
\hline Forest Fire Danger Index ${ }^{1}$ & $<10$ & $5-11$ \\
\hline FFDI following day & $<12$ & $<12$ \\
\hline Bark Fuel Moisture Content (\%) & $12-14 \%$ & \\
\hline Surface Fuel Moisture (\%) & $>18 \%$ & $11-16$ \\
\hline Profile Fuel Moisture (\%) & $>20 \%$ & \\
\hline Wind speed $(\mathbf{k m} / \mathbf{h})$ & $<20$ (forecast) $<15$ subcanopy & $<20$ Forecast $<15$ subcanopy \\
\hline Relative Humidity (\%) & $35-65$ for at least 4 hours & $30-70$ \\
\hline Keetch Byram Drought Index ${ }^{2}$ & $<80$ & $<50$ \\
\hline
\end{tabular}

${ }^{1}$ (McArthur 1967), ${ }^{2}$ (Keetch and Byram 1968)

Candling can be done where there are large accumulations of suspended materials where there is sufficiently connectivity to allow burning or on trees with loose fibrous bark on the entire tree bole (Fig 2A). Ignitions can be done using hand held drip torches (Fig 2B) or vehicular flame throwers. The lighting of rings of fire around the base of trees will promote fire driven convection and will allow the fire to climb the bole of the tree. As there is no spread between trees or fuel accumulations, each needs to be lit separately, so the process is labour intensive. 


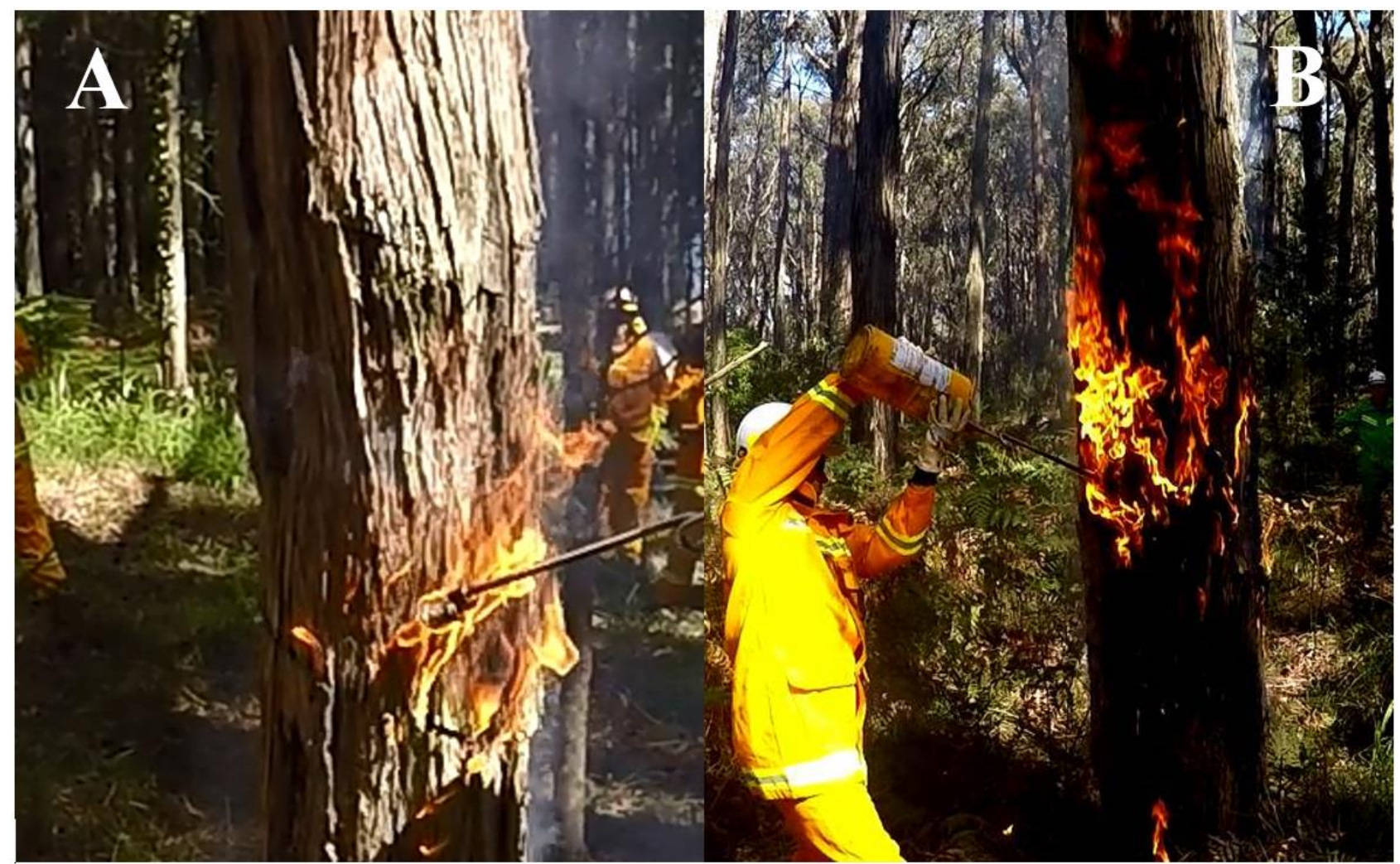

Figure 2 - A) Fibrous bark of Eucalyptus Obliqua. B) Candling of E. obliqua during winter in South Eastern Australia

\subsection{Analysis of data}

We compared the conditions under which prescribed burning and candling can be done for a forested site in Victoria, Australia using historic Automatic Weather Station Data. We used the Scoresby Research Institute weather station http://www.bom.gov.au/climate/averages/tables/cw_086104.shtml), as it is in an area that has a strong presence of Eucalyptus obliqua (Messmate stringybark), a species notorious for firebrands. Data were obtained representing daily weather conditions for the period from June 30, 2011 to December 30, 2016. We used burn prescriptions to compare the proportion of the year under which candling can be completed in comparison to prescribed burning. The prescriptions used for candling are presented in Table 1, however as daily data were used, RH and fuel moisture constraints were excluded, and a maximum $3 \mathrm{pm}$ wind speed of $20 \mathrm{~km} / \mathrm{h}$ was used instead of FFDI. The prescriptions used to represent prescribed burning are those for dry sclerophyll forest (regrowth, without wiregrass) obtained from DELWP. As the prescriptions are intended to represent the maximum safe burning conditions, the conditions where it was too wet to undertake prescribed burning were determined to be these where the McArthur Drought Factor was less than 6 as determined by Duff et al. (2018). The summer months (from December to March) were excluded from the analysis since during this period there are fire restrictions to limit the potential for wildfires. The first six months of the KBDI data for the period analysed were excluded from analysis to allow the algorithm to equilibrate, since KBDI calculations are done using an account keeping process.

\section{Results and Discussion}

We found that candling can be done for a much larger proportion of the year than prescribed burning. Over the study period, on average 124 days per year were suitable for candling, 48 days more 
than the 76 day window available for prescribed burning. Much of the time suitable for candling was coincident with that for burning (Fig 3), however candling could also be done after rain events when it was too wet for effective prescribed burning. Candling could be done for the entire winter period, whereas prescribed burning was limited to the autumn and spring.

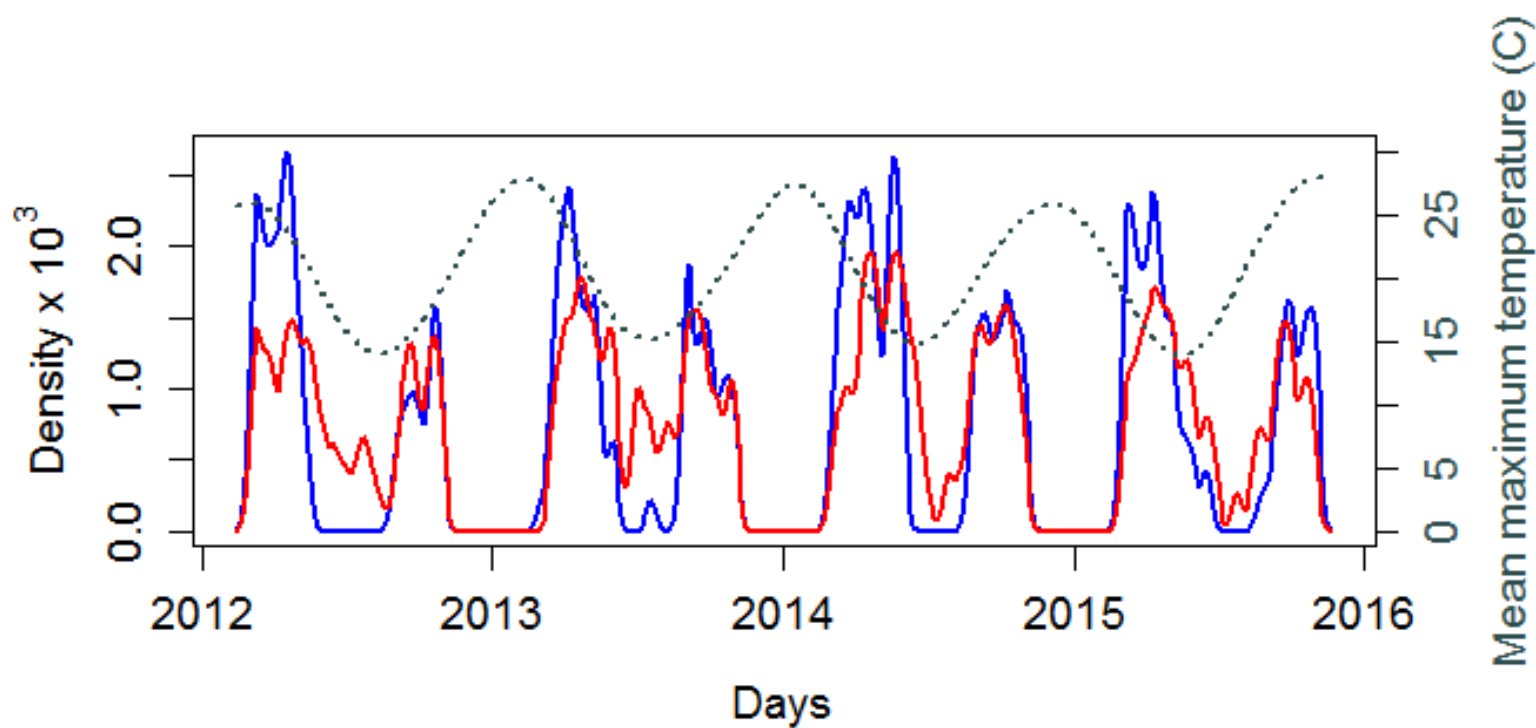

Figure 3 - A) Density plots of the days available for prescribed burning (blue) and candling (red). To facilitate plotting, a density bandwidth of 6 days was used. Maximum temperature is shown using a grey dotted line that has been smoothed with a 25 day moving window.

This means that candling has the potential to allow wildfire risk reduction activities to be undertaken at times when fire crews are not currently active. At these times, due to the non-flammable landscape there is little to no chance of fire escape. In the WUI, bark fuels pose a major issue for house loss, and so prescribed burns are difficult to implement due the high levels of consequences if there is an escape. Candling is potentially an effective means to safely and cheaply reduce asset exposure to firebrands during wildfires and prescribed burning. As it has limited effect on vegetation structure, it may also be more socially acceptible than burning.

As burn escapes are commonly a result of firebrands (Dether and Black 2006), candling can be applied as a complimentary measure to burning by reducing the likelihood of escape by pre-treating trees around the burn perimeter. Such an approach could also be used adjacent to existing firebreaks in the landscape to reduce the likelihood that they are breached during fires and enhance the safety of fire suppression crews.

Candling is one of a number of approaches that can be used to manage aerial dead fire fuels that contribute to crowning and spotting. It has advantages in contrast to other approaches that warrant its consideration in fire risk planning, although its limitations need to be recognised (Table 2). 
Table 2 - Advantages and disadvantages of ladder fuel treatment approaches

\begin{tabular}{|c|c|c|}
\hline Practice & Advantages & Disadvantages \\
\hline \multirow{6}{*}{$\begin{array}{l}\text { Prescribed } \\
\text { burning }\end{array}$} & Reduce a wide variety of fuels & The chance of escape and loss \\
\hline & Complex to safely undertake & Limited seasonal window \\
\hline & Efficient over large areas & Cannot be done in all places \\
\hline & Can have desirable ecological outcomes & High biomass consumption \\
\hline & & Potential for unwanted ecological outcomes \\
\hline & & May have high canopy mortality \\
\hline Mechanical & Reduces live and dead ladder fuels & Requires specialised equipment \\
\hline \multirow[t]{4}{*}{ Treatment } & Does not depend on a burn window & Expensive over large areas \\
\hline & & May increase surface fuels \\
\hline & & May have unwanted ecosystem outcomes \\
\hline & & $\begin{array}{l}\text { Not a suitable method for reducing bark fuels unless } \\
\text { entire tree removed }\end{array}$ \\
\hline \multirow[t]{7}{*}{ Candling } & Reduces fine dead ladder and bark fuels & Labour intensive \\
\hline & Low chance of escape & Limited research on how fire behaviour is affected \\
\hline & Low likelihood of ecological damage & Not suited for all vegetation types \\
\hline & Requires no specialised equipment & Limited research on ecological impacts \\
\hline & $\begin{array}{l}\text { Can be done where it is too dangerous to burn } \\
\text { (i.e. WUI) }\end{array}$ & \\
\hline & $\begin{array}{l}\text { Has a wider seasonal window than prescribed } \\
\text { burning }\end{array}$ & \\
\hline & Low biomass consumption & \\
\hline
\end{tabular}

Candling is currently used operationally in the state of Victoria, Australia. It has had limited operational adoption outside this state or elsewhere. The effectiveness of candling has been inferred from the effect it has on dead aerial fine fuels, particularly bark. However, to-date there has been no empirical research into how candling modifies fire behaviour, fire brand production and the relative levels of exposure that assets and firebreaks will be exposed to during wildfires. As a result, it is unclear how much effort and investment fire agencies should direct towards candling.

To effectively integrate candling as a treatment into a fire risk management program, further research is warranted. This should include:

- Quantifying the effect candling has on fuel properties in different vegetation communities;

- Determining differences in fire behaviour and ember production in treated areas;

- Developing models of fuel recovery after treatment;

- Determining the environmental factors that influence candling outcomes;

- Determining the optimal spatial configurations of candling in the landscape to have the greatest moderating effect on fire behaviour;

- Evaluating the ecological impacts of candling;

- Comparison of the outcomes of different candling techniques (including conditions and methods); and

- Consideration of how to account for candled areas in landscape fire simulation systems used in risk planning.

As its application has had limited use outside a single jurisdiction, potential applications may have not been considered. For example, it may be effective in North American systems to reduce dead canopy needles in locations where there has been widespread death of conifers due to bark beetles (Jenkins et al. 2012). 


\section{Conclusion}

Candling is a technique that can be used to manage dead fine aerial fuels, particularly fibrous bark. Its adoption for operational use has been extremely limited and is restricted to South Eastern Australia. Its practice requires few material resources and it can be undertaken for wider burning window than is available for prescribed burning. However, while its efficacy can be inferred from the way it modifies fuels, there is currently no empirical research describing how it modifies wildfire risk or modifies ecosystem processes. Given the challenges posed to fire managers worldwide by eucalyptus firebrands, candling is a technique that warrants consideration and further investigation.

\section{Acknowledgements}

This work was funded in-part by the Country Fire Authority of Victoria, and the Victorian Department of Environment, Land, Water and Planning. We gratefully acknowledge their contributions.

\section{References}

Alexander, ME, Cruz, MG (2011) What are the safety implications of crown fires? . In 'Proceedings of 11th International Wildland Fire Safety Summit. Missoula, Montana, USA.', April 4-8, 2011. ( International Association of Wildland Fire)

Billing, P, Bywater, JV (1982) Using fire to reduce aerial fuels in first thinned radiata pine. Forest Commission, Victoria No. 16, Melbourne, Australia.

Blanchi, R, Leonard, J (2005) Investigation of bushfire attack mechanisms resulting in house loss in the ACT bushfire 2003. Bushfire CRC, East Melbourne, Australia.

Chatto, K, Bell, TL, Kellas, JD (2003) Effects of repeated low-intensity fire on tree growth and bark in a mixed Eucalypt foothill forest in south-eastern Australia. Department of Sustainability and Environment No. 66, East Melbourne, Victoria, Australia.

Cheney, NP, Bary, GAV (1969) The propagation of mass conflagrations in a standing eucalypt forest by the spotting process. In ' Mass fire symposium: collected papers. Canberra', 10-12 February 1969. (Commonwealth of Australia, Defence Standard Laboratories: Melbourne)

Cruz, MG, Sullivan, AL, Gould, JS, Sims, NC, Bannister, AJ, Hollis, JJ, Hurley, RJ (2012) Anatomy of a catastrophic wildfire: The Black Saturday Kilmore East fire in Victoria, Australia. Forest Ecology and Management 269-285.

Dether, D, Black, A (2006) Learning from escaped prescribed fires - lessons for high reliability. Fire Management Today 66, 50-56.

Duff, T, J., Cawson, J, G., Harris, S (2018) Dryness thresholds for fire occurrence vary by forest type along an aridity gradient: evidence from Southern Australia. Landscape Ecology

Ellis, PFM (2011) Fuelbed ignition potential and bark morphology explain the notoriety of the eucalypt messmate 'stringybark' for intense spotting. International Journal of Wildland Fire 20, 897-907.

Hines, F, Tolhurst, K, G., Wilson, AG, McCarthy, GJ (2010) Overall fuel hazard assessment guide, 4th Edition. Department of Sustainability and Environment Victoria, Melbourne, Melbourne.

Hoffman, CM, Canfield, J, Linn, RR, Mell, W, Sieg, CH, Pimont, F, Ziegler, J (2016) Evaluating crown fire rate of spread predictions from physics-based models. Fire Technology 221-237.

Jenkins, MJ, Page, WG, Hebertson, EG, Alexander, ME (2012) Fuels and fire behavior dynamics in bark beetle-attacked forests in Western North America and implications for fire management. Forest Ecology and Management 275, 23-34. 
Keetch, JJ, Byram, GM (1968) A drought index for forest fire control. Forest Service, U.S. Department of Agriculture, Ashville, North Carolina.

Koo, E, Pagni, PJ, Weise, DR, Woycheese, JP (2010) Firebrands and spotting ignition in large-scale fires. International Journal of Wildland Fire 19, 818-843.

McArthur, AG (1967) Fire behaviour in Eucalypt forests. Forestry and Timber Bureau, Department of National Development, Canberra, Australia.

Penman, TE, Cawson, JG, Murphy, S, Duff, TJ (2017) Messmate Stringybark: bark ignitability and burning sustainability in relation to fragment dimensions, hazard and time since fire. International Journal of Wildland Fire

Slijepcevic, A, Anderson, WR, Matthews, S, Anderson, DH (2015) Evaluating models to predict daily fine fuel moisture content in eucalypt forest. Forest Ecology and Management 335, 261-269.

Stephens, SL, Finney, MA (2002) Prescribed fire mortality of Sierra Nevada mixed conifer tree species: effects of crown damage and forest floor combustion. Forest Ecology and Management $162,261-271$.

Tolhurst, KG, Cheney, NP (1999) Synopsis of the knowledge used in prescribed burning in Victoria. Department of Natural Resources and Environment, East Melbourne, Victoria, Australia. 